\title{
A PEDIGREE OF DEFICIENCY OF THE NINTH COMPONENT OF COMPLEMENT (C9)
}

\author{
Tomohiro Kusaba, ${ }^{1}$ Tatsuro Kisu, ${ }^{1}$ Shoichi Inaba, ${ }^{2}$ Kouko SaKaI, ${ }^{3}$ \\ Kazuo OKOCHI, ${ }^{4}$ and Toshiyuki YANASE ${ }^{1}$ \\ ${ }^{1}$ First Department of Internal Medicine, Faculty of Medicine, Kyushu University, \\ Fukuoka 812, Japan \\ ${ }^{2}$ Blood Transfusion Service, Kyushu University Hospital, Fukuoka 812, Japan \\ ${ }^{3}$ National Fukuoka Central Hospital, Fukuoka 812, Japan \\ ${ }^{4}$ Central Clinical Laboratories, Kyushu University Hospital, \\ Fukuoka 812, Japan
}

\begin{abstract}
Summary Findings in a large family with a hereditary deficiency of the ninth component of complement (C9) were reported. The proposita was a 64-year-old Japanese woman with gastric cancer. C9 was undetectable by both rocket immunoelectrophoresis and hemolytic assays. Despite the C9 deficiency her serum showed half the normal level of hemolytic complement activity $(16 \mathrm{CH} 50 \mathrm{U} / \mathrm{ml}) . \quad \mathrm{C} 9$ was not detectable in her two sisters who had no underlying disease. Other complement components were of normal levels in these two sisters. In 8 males and 7 females from three generations of the family, levels of C9 protein were reduced and ranged from 22 to $46 \%$ of the normal. Such corresponds to heterozygote for the mutant gene, and this defect may be due to autosomal incompletely dominant gene.
\end{abstract}

The $\mathrm{C} 9$ deficient individuals were not liable to specific diseases.

\section{INTRODUCTION}

The hereditary defects heretofore reported mostly involved the classical pathway of complement components (Alper and Rosen, 1979; Agnello, 1978). Since the report of the first case of C9 deficiency by Inai et al. (1979), other occurrences in Japan have also been documented (Kisu et al., 1980; Yukiyama et al., 1979; Amano et al., 1980; Kawano et al., 1980).

Received October 1, 1983

All communication and reprint requests to Dr. T. Kusaba.

This work was supported by Grant-in-Aid for Scientific Research to T. Yanase from the Ministry of Health and Welfare of Japan, a Grant (No. 58440042) from the Ministry of Eduction, Science and Culture of Japan, and The Mitsubishi Foundation. 
We now report the chemical and immunological findings in members of a large family with $\mathrm{C} 9$ deficiency.

\section{MATERIALS AND METHODS}

Blood samples taken from the family members allowed to clot at room temperature, and the sera were stored at $-80^{\circ} \mathrm{C}$.

Complement assays: The total hemolytic activity of complement in serum (CH50) was measured by the method of Mayer (1961) using only $1 / 2.5$ the volume of the reagents (Nagaki et al., 1965). Hemolytic activities of serum complement components were measured using microtiter plate assay (Nelson et al., 1966) and appropriate intermediate cells and reagents respectively. Purified human $\mathrm{C}$, a commercial product from Cordis Laboratories, Inc., Miami, U.S.A., was used for the restoration test of hemolytic activity in the C9 deficient serum, and anti-C9 rabbit antiserum (Behringwerke AG, Marburg, West Germany) for measurement of C9 protein by rocket immunoelectrophoresis. Anti-C9 antiserum was added to the buffered agarose gel (Agarose A45, Nakarai chemical Co., Japan) at 3\% of final concentration, and the electrophoresis were performed for about $18 \mathrm{hr}$ with a potential drop of $2 \mathrm{v} / \mathrm{cm}$.

Serum protein concentrations of $\mathrm{C} 3$ and $\mathrm{C} 4$ were measured by radial immunodiffusion using a commercially available immunodiffusion plate (Partigen, Behringwerke AG, Marburg, West Germany).

\section{RESULTS}

Titration of hemolytic activities of serum complement components

In the proposita and her two sisters, as shown in Table 1, hemolytic activities of $\mathrm{C} 9$ were not detectable, though those of other complement components, $\mathrm{C} 1$ to C8, were within normal limits in the latter two. In the proposita's serum, however, hemolytic activities of $\mathrm{C} 4, \mathrm{C} 2, \mathrm{C} 3, \mathrm{C} 5, \mathrm{C} 6$, and $\mathrm{C} 7$ were also depressed, suggesting that other factor(s) affects the hemolytic activities of these components in the serum of the proposita, as a carcinoma-bearing host. Amounts of $\mathrm{C} 4$ and $\mathrm{C} 3$ proteins were normal (Table 3). The absence of $\mathrm{C} 9$ protein in these sera was also confirmed by the method of single radial immuno-diffusion and rocket immunoelectrophoresis (Kisu et al., 1980). Hemolytic activities of C9 in sera of two brothers of the proposita were reduced to $1 / 4$ and $1 / 8$ of that in normal human serum, respectively, the other components being within normal ranges.

Restoration of the whole hemolytic activity by the addition of isolated C9 in the C9 deficient sera

As shown in Fig. 1, various amounts of functionally pure $C 9(0.04-100 \mathrm{U} / \mathrm{ml})$ were added to C9 deficient sera from two sisters (II-3 and II-15) for restoration test, 
Table 1. Hemolytic activities of serum complement components in the C9 deficient members of the family.

\begin{tabular}{lcrrrrrrrrrr}
\hline \multirow{2}{*}{$\begin{array}{l}\text { Deficiency } \\
\text { state }\end{array}$} & $\begin{array}{c}\text { Case } \\
\text { number }\end{array}$ & \multicolumn{6}{c}{ Hemolytic activities of serum complement components } \\
\cline { 5 - 11 } & C1 & C4 & C2 & C3 & C5 & C6 & C7 & C8 & C9 \\
\hline $\begin{array}{l}\text { Homozygous } \\
\text { deficiency }\end{array}$ & II-3 & 800 & 3,200 & 1.600 & 1,600 & 3,200 & 12,800 & 6,400 & 6,400 & $<200$ \\
& II-6 & 6,400 & $<200$ & $<200$ & $<200$ & $<200$ & $<200$ & $<200$ & 1,600 & $<200$ \\
& II-15 & 1,600 & 1,600 & 1,600 & 800 & 3,200 & 3,200 & 1,600 & 1,600 & $<200$ \\
\hline $\begin{array}{l}\text { Heterozygous } \\
\text { deficiency }\end{array}$ & II-10 & 1,600 & 3,200 & 800 & 800 & 3,200 & 3,200 & 1,600 & 1,600 & 400 \\
& II-17 & 3,200 & 800 & 1,600 & 1,600 & 3,200 & 6,400 & 3,200 & 6,400 & 200 \\
\hline No deficiency & II-8 & 1,600 & 3,200 & 800 & 400 & 6,400 & 3,200 & 800 & 3,200 & 1,600 \\
& II-13 & 1,600 & 6,400 & 1,600 & 800 & 800 & 3,200 & 1,600 & 3,200 & 800 \\
\hline Healthy control & & 3,200 & 3,200 & 3,200 & 1,600 & 1,600 & 6,400 & 6,400 & 12,800 & 1,600 \\
\hline
\end{tabular}

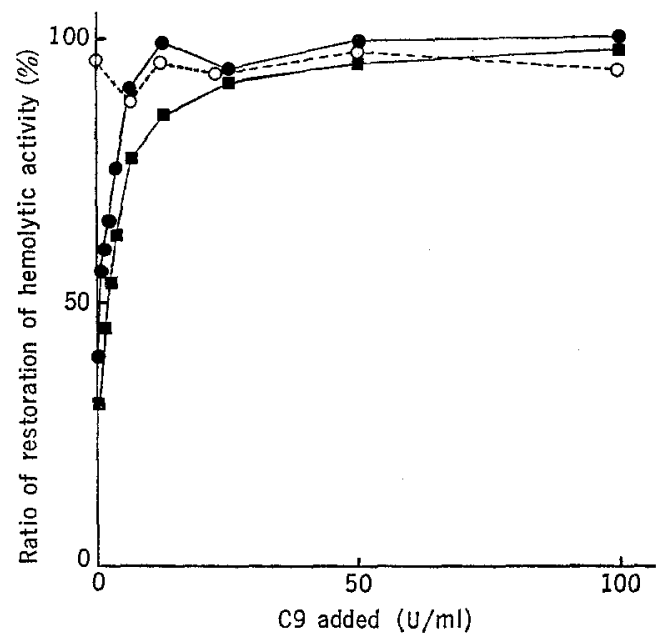

Fig. 1. Restoration of serum complement hemolytic activity by adding various concentrations of isolated $\mathrm{C} 9$ in the $\mathrm{C} 9$ deficient serum. $\mathbf{0}, \mathbf{n}$, homozygote (II-3 and $\Pi-15$ in Fig. 2, respectively); 0 , healthy control.

and the results in full restoration of the hemolytic activity were obtained by addition of more than $6.25 \mathrm{U} / \mathrm{ml}$ of $\mathrm{C}$, but no sign of restoration was evident in the case of the proposita's serum.

Restoration of $C 9$ hemolytic activity by the addition of isolated $C 9$ in the $C 9$ deficient sera

C9 hemolytic activity in the C9 deficient sera was measured using EAC1-8 intermediate cells. Isolated $\mathrm{C} 9$ of various concentrations were added to a mixture 
Table 2. Restoration of $\mathrm{C} 9$ hemolytic activity by adding various concentrations of isolated $\mathrm{C} 9$ in the $\mathrm{C} 9$ deficient serum.

\begin{tabular}{|c|c|c|c|c|c|c|c|c|c|c|c|c|}
\hline & \multicolumn{12}{|c|}{ Amounts of isolated $\mathrm{C} 9$ added $(\mathrm{U} / \mathrm{ml})$} \\
\hline & 100 & 50 & 25 & 12.5 & 6.25 & 3.13 & 1.57 & 0.79 & 0.40 & 0.20 & 0.10 & 0 \\
\hline \multirow{2}{*}{ III-3 } & 4 & 4 & 4 & 3 & 2 & 2 & 1 & 1 & 0 & 0 & 0 & 0 \\
\hline & 4 & 4 & 4 & 3 & 2 & 1 & 1 & 0 & 0 & 0 & 0 & 0 \\
\hline \multirow{2}{*}{ II-6 } & 3 & 0 & 0 & 0 & 0 & 0 & 0 & 0 & 0 & 0 & 0 & 0 \\
\hline & 2 & 0 & 0 & 0 & 0 & 0 & 0 & 0 & 0 & 0 & 0 & 0 \\
\hline \multirow{2}{*}{ II-15 } & 4 & 4 & 4 & 3 & 2 & 2 & 1 & 1 & 0 & 0 & 0 & 0 \\
\hline & 4 & 4 & 3 & 2 & 2 & 1 & 1 & 0 & 0 & 0 & 0 & 0 \\
\hline \multirow{2}{*}{$\begin{array}{l}\text { Healthy } \\
\text { control }\end{array}$} & 4 & 4 & 4 & 4 & 4 & 4 & 4 & 4 & 4 & 4 & 4 & 4 \\
\hline & 4 & 4 & 4 & 4 & 4 & 4 & 4 & 4 & 4 & 4 & 4 & 4 \\
\hline
\end{tabular}

$0,1,2,3$ and 4 showing degree of hemolysis; 4 : complete lysis, $0:$ no lysis. Test for restoration duplicated on each $\mathrm{C} 9$ deficient serum.

of EACl-8 cells and C9 deficient sera, As shown in Table 2, addition of 25 to 100 $\mathrm{U} / \mathrm{ml}$ of functionally pure $\mathrm{C} 9$ to sera from $\mathrm{C} 9$ deficient siblings (II-3 and II-15) resulted in full restoration of the hemolytic activity, and addition of 0.79 to 12.5 $\mathrm{U} / \mathrm{ml}$ of $\mathrm{C} 9$ resulted in partial restoration of hemolytic activity, suggesting that there were no inhibitory factor(s) to $\mathrm{C} 9$ hemolytic activity in these sera.

On the other hand, addition of $\mathrm{C} 9$ of relatively high concentrations partially restored the hemolytic activity in the proposita's serum, indicating that some inhibitory factor(s) for C9 were present in the proposita's serum.

\section{Family studies}

Table 3 shows the levels of $\mathrm{CH} 50, \mathrm{C} 3, \mathrm{C} 4$, and $\mathrm{C} 9$ in sera from members of the kindred. In the $\mathrm{C} 9$-deficient individuals, the values of $\mathrm{CH} 50$ were only slightly reduced and ranged from 16 to $23 \mathrm{U} / \mathrm{ml}$, those of $\mathrm{C} 3$ and $\mathrm{C} 4$ proteins being within normal ranges.

Fifteen individuals of the family showed reduced C9 levels, comprising 22 to $46 \%$ of the value of a pooled serum from 450 healthy adults (standard serum). These findings indicate that these individuals possessed heterozygous state for the C9 mutant gene. In these heterozygotes $\mathrm{C} 3$ and $\mathrm{C} 4$ as well as $\mathrm{CH} 50$ were within normal limits, except III-13. The family tree is shown in Fig. 2.

Individual tests of 337 sera from healthy adults were performed in order to investigate the normal range of $\mathrm{C} 9$ protein by rocket immunoelectrophoresis and expressed as a percentage of the concentration of $\mathrm{C} 9$ protein in the standard serum.

The distribution of $\mathrm{C} 9$ values in sera from healthy adults was shown in Fig. 3. The mean value and standard deviation (1S) was equal to $95.8 \pm 26.2 \%$ of the $\mathrm{C} 9$ 


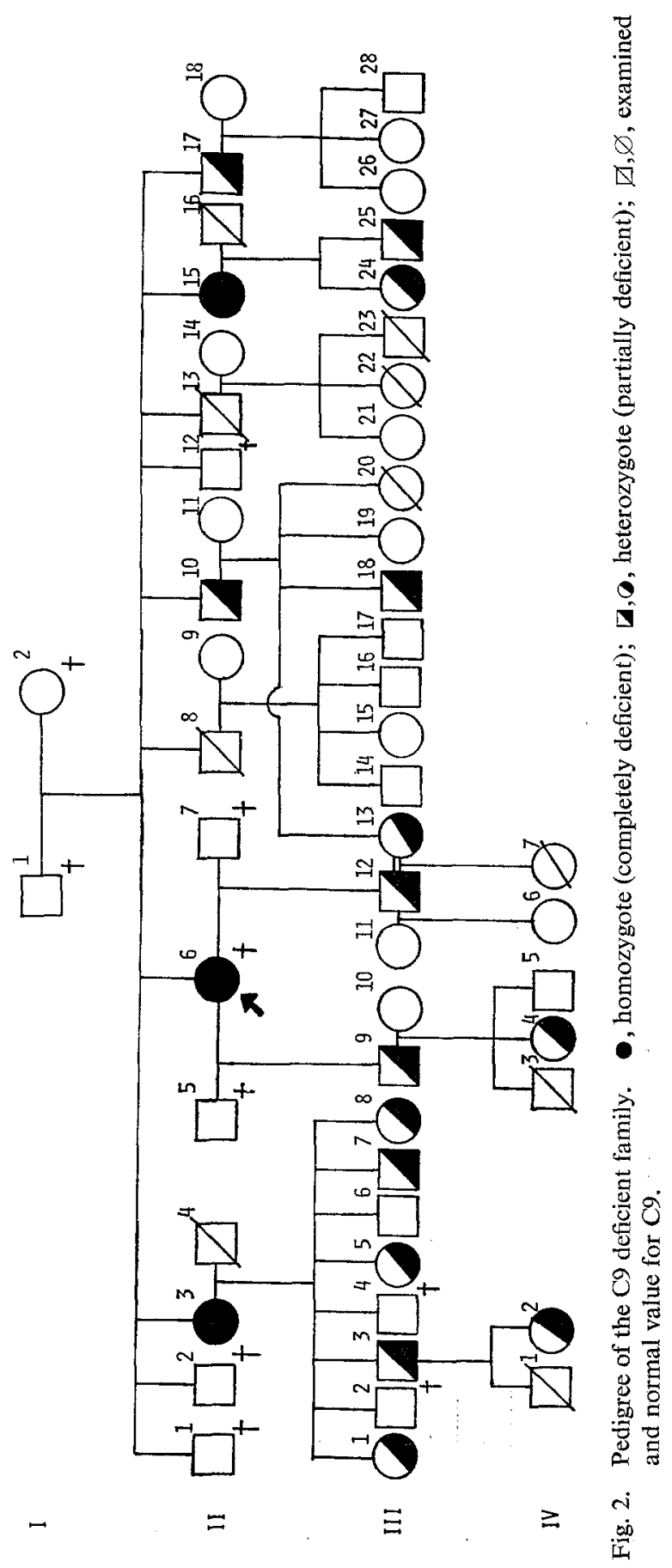

Vol. 28, No. 4, 1983 
Table 3. Values of $\mathrm{CH} 50, \mathrm{C3}-\mathrm{C4}$ - and $\mathrm{C} 9$ protein in the family members of $\mathrm{C} 9$ deficiency.

\begin{tabular}{|c|c|c|c|c|}
\hline & $\mathrm{CH} 50(\mathrm{U} / \mathrm{ml})$ & C3 (mg/dl) & $\mathrm{C} 4(\mathrm{mg} / \mathrm{dl})$ & $\mathrm{C} 9(\%)$ \\
\hline II $-3 * *$ & 16 & 109 & 60 & 0 \\
\hline II. 4 & 52 & 80 & 37 & 98 \\
\hline II $-6^{* * *}$ & 23 & 115 & 80 & 0 \\
\hline $10-8$ & 40 & 78 & 54 & 84 \\
\hline II-10* & 42 & 78 & 54 & 35 \\
\hline II-13 & 66 & 90 & 50 & 95 \\
\hline II-15** & 16 & 95 & 54 & 0 \\
\hline II-16 & 55 & 75 & 52 & 98 \\
\hline II $-17^{*}$ & 52 & 101 & 62 & 35 \\
\hline III- $1^{*}$ & 60 & 98 & 43 & 36 \\
\hline III- $3^{*}$ & 60 & 86 & 44 & 22 \\
\hline III- 5* & 52 & 86 & 44 & 38 \\
\hline III- $7^{*}$ & 42 & 86 & 60 & 32 \\
\hline III- $8^{*}$ & 46 & 75 & 39 & 34 \\
\hline III- $9^{*}$ & NT & $\mathrm{NT}$ & NT & 33 \\
\hline III- $12 *$ & NT & NT & NT & 33 \\
\hline III-13* & 23 & 70 & 44 & 42 \\
\hline III-18* & 30 & 64 & 38 & 36 \\
\hline III-20 & 29 & 88 & 41 & 96 \\
\hline III-22 & 39 & 90 & 56 & 120 \\
\hline III-23 & 36 & 82 & 34 & 75 \\
\hline III-24* & 70 & 110 & 77 & 46 \\
\hline III $-25^{*}$ & 39 & 86 & 34 & 34 \\
\hline IV- 1 & 37 & 112 & 37 & 68 \\
\hline IV $-2^{*}$ & 39 & 119 & 30 & 39 \\
\hline IV- 3 & 37 & 112 & 36 & 65 \\
\hline IV $-4 *$ & 45 & 147 & 62 & 39 \\
\hline IV -7 & 32 & 125 & 58 & 80 \\
\hline
\end{tabular}

** Homozygous deficiency, * heterozygous deficiency. $\mathrm{C} 9,100 \%=250$ pooled NHS; NT, not tested.

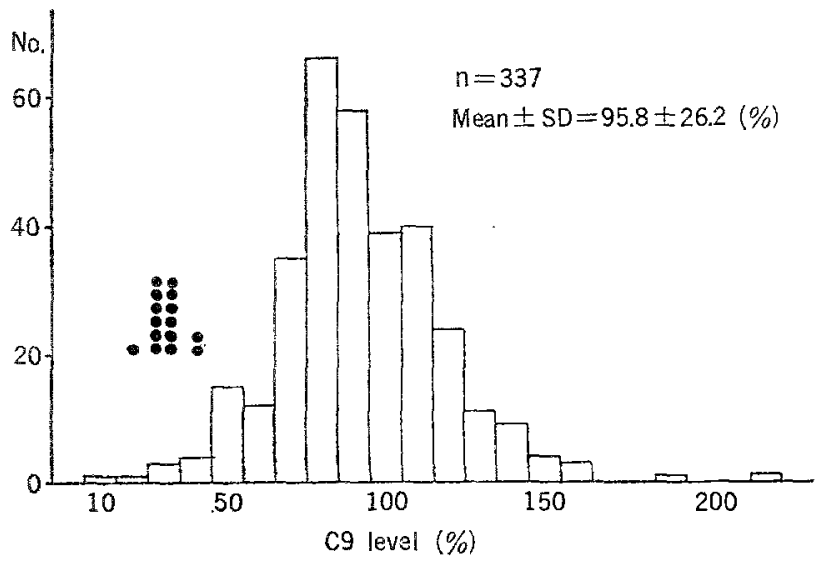

Fig. 3. Distribution of $\mathrm{C} 9$ protein levels in healthy adults and proposed-heterozygous $\mathrm{C} 9$ deficient individuals. $100 \%=$ pooled normal human serum $(n=450)$. posed-heterozygous $\mathrm{C} 9$ deficient individual.

Jpn. J. Human Genet. 
value in the standard serum. Nine of 337 healthy adults $(2.7 \%)$ showed low C9 level less than half of the standard serum.

Closed circle in Fig. 3 represented the serum $C 9$ values of individuals assumed to be heterozygous for $\mathrm{C} 9$ deficiency.

\section{DISCUSSION}

Hereditary defects of complement components reported thus far mostly involved the classical pathway in human, including C1r (Pickering et al., 1971), C1s (Pondman et al., 1968), C4 (Hauptmann et al., 1974), C2 (Klemperer et al., 1966), C3 (Ballow et al., 1975), C5 (Rosenfeld et al., 1976), C6 (Leddy et al., 1974), C7 (Boyer et al., 1975; Gelâge et al., 1977; Nemerow et al., 1978), and C8 (Petersen et al., 1976), and two inactivators of the complement system, $\mathrm{Cl}$ inhibitor (Donaldson and Evans, 1963), and C3b inactivator (Abramson et al., 1971; Thompson and Lachmann, 1977). Few cases of ninth component (C9), the terminal component of the complement sequence, have been reported.

Inai et al. (1979) were the first to report a case of deficiency of C9 in a 29-yearold healthy woman, and seven families with C9 deficiency have recently been detected in Japan (Kisu et al., 1980; Yukiyama et al., 1979; Amano et al., 1980; Kawano et al., 1980). Lint et al. (1980) recently reported such an occurrence in a Caucasian man. These findings suggest that the frequency of C9 deficiency may not be so rare. The proposita of this study, a 64-year-old woman, was first identified to be $\mathrm{C} 9$ deficient since the precipitating anti-C9 antibody was found in the serum after having received the blood transfusions (Okochi and Inaba, 1980). Despite the deficiency of $\mathrm{C} 9$, the proposita's serum showed half the normal hemolytic activity.

Studies on all family members revealed that two sisters were also completely deficient in C9 and fifteen members had levels of less than half of the normal. The former two would correspond to individuals homozygous for the mutant gene, as was the proposita, and the latter fifteen to heterozygous ones. This defect may be due to an autosomal, incompletely dominant gene. Level of protein was zero in homozygous individuals, and less than half the normal in heterozygous individuals, the levels of $\mathrm{C} 9$ protein ranging from 22 to $46 \%$ of the normal. Thus, levels of $\mathrm{C} 9$ protein in serum of normal homozygote $\left(\mathrm{C}_{9}, \mathrm{C}_{9}\right)$, heterozygote $\left(\mathrm{C}_{9}, \overline{\mathrm{C}}_{9}\right)$, and deficient homozygote $\left(\overline{\mathrm{C}}_{9}, \overline{\mathrm{C}}_{9}\right)$ approximately reflected the dosage effect of the wild type and mutant gene. Some of the known defects of complement components in man, including C2 (Klemperer et al., 1966; Fu et al., 1974; Day et al., 1975), C3 (Alper and Rosen, 1979), C5 (Rosenfeld et al., 1976; Snyderman et al., 1979), C6 (Leddy et al., 1974; Lim et al., 1976; Glass et al., 1978), C7 (Boyer et al., 1975; Gelâge et al., 1977; Nemerow et al., 1978), and C8 (Petersen et al., 1976) appear to be inherited in the same mode as is C9. One of the well documented exceptions to this mode of inheritance is the deficiency of $\mathrm{Cl}$ inhibitor (Donaldson and Evans, 1963), causative pathogenesis of hereditary angioedema. In the studies of inherited C6 deficiency 
Glass et al. (1978) infered that a low level of serum C6 in individuals with a C6 deficiency results from the heterozygous state of normal $\mathrm{C} 6$ variant gene and a silent or null C6 gene. Pariser et al. (1978) reported that hereditary $\mathrm{C} 2$ deficiency was determined by the same mechanisms involved in the deficiency of C6.

Consanguineous marriage was not identified in the past few generations of the proposita.

None of $\mathrm{C} 9$ deficient individuals in this family appear to be liable to some specific ill conditions as a result of this deficiency, excepting that the untoward proposita died with a gastric cancer, as did others with a complete C9 deficiency (Inai et al., 1979; Amano et al., 1980; Kawano et al., 1980). It was reported that only one male showed a tendency to have repeated infections (Yukiyama $e^{t}$ al., 1979) and a child had an anamnesis of anaphylactoid purpura (Kawano et al., 1980).

Lint et al. (1980) reported that C9 deficiency was not linked to the HLA-A or $B$ antigens. We obtained no evidence suggesting a close linkage between $\mathrm{C} 9$ deficiency and major histocompatibility loci (Sato, 1980). Also, there was no linkage between $\mathrm{C} 9$ deficiency and the blood group system including $\mathrm{ABO}, \mathrm{Rh}$, Lutheran, Kell, MNS, P, Duffy, Kidd, Diego, and Xg (Otsuka, 1980).

Acknowiedgement We thank M. Ohara for comments on the manuscript. Excellent technical assistance was provided by Miss K. Futamura and secretarial assistance by Miss N. Nagamatsu.

\section{REFERENCES}

Abramson, N., Alper, C.A., Lachmann, P.J., Rosen, F.S., and Jandl, J.H. 1971. Deficiency of C3 inactivator in man. J. Immunol. 107: 19-27.

Agnello, V. 1978. Complement deficiency states. Medicine 57:1-23.

Alper, C.A., and Rosen, F.S. 1979. Human complement deficiencies. In Mechanisms of Immunopathology, Cohen, S., Ward, P.A., McCluskey, R.T., eds., John Wiley \& Sons, Inc., New York, p. 289-305.

Amano, T., Miyashima, H., Mihashi, Y., Sato, M., Ofuji T., Takasugi, K., Nakahara, Y., Yoshinouchi, T., Ogura, T., and Kitamura, H. 1980. Three cases of deficiency of ninth component of complement. Proceedings of the 8th Japanese Congress of Clinical Immunology. p. 256 (Abstract in Japanse).

Ballow, M., Shira, J.E., Harden, L., Yang, S.Y., and Day, N.K. 1975. Complete absence of the third component of complement in man. J. Clin. Invest. 56: 703-710.

Boyer, J.T., Gall, E.P., Norman, M.E., Nilsson, U.R., and Zimmerman, T.S. 1975. Hereditary deficiency of the seventh component of complement. J. Clin. Invest. 56:905-913.

Day, N.K., Lesperance, P., Good, R.A., Michael, A.F., Hansen, J.A., Dupont, B., and Jersild, C. 1975. Hereditary C2 deficiency: Genetic studies and association with the HL-A system. J. Exp. Med. 141: 1464-1469.

Delâge, J.M., Bergeron, P., Simard, J., Lehner-Netsch, G., and Prochazka, E. 1977. Hereditary C7 deficiency. J. Clin. Invest. 60: 1061-1069.

Donaldson, V.H., and Evans, R.R. 1963. A biochemical abnormality in hereditary angioneurotic edema. Am. J. Med. 35: 37-44.

Fu, S.M., Kunkel, H.G., Brusman, H.P., Allen, F.H., Jr., and Fotino, M. 1974 . Evidence for

Jpn. J. Human Genet. 
linkage between HL-A histocompatibility genes and those involved in the synthesis of the second component of complement. J. Exp. Med. 140: 1108-1111.

Glass, D., Raum, D., Balavitch, D., Kagan, E., Rabson, A., Schur, P.H., and Alper, C.A. 1978. Inherited deficiency of the sixth component of complement: A silent or null gene. J. Immunol. 120: $538-541$.

Hauptmann, G., Grosshans, E., Heid, E., Mayer, S., and Basset, A. 1974. Lupus erythémateux aigu avec déficit complet de la fraction C4 du complement. Nouv. Pres, Med. 3: 881-882.

Inai, S., Kitamura, H., Hiramatsu, S., and Nagaki, K. 1979. Deficiency of the ninth component of complement in man. J. Clin. Lab. Immunol. 2: 85-87.

Kawano, A., Yamamoto, K., Migita, S., and Takiguchi, T. 1980. A familial case of hereditary C9 deficiency. Proceedings of the Complement Symposium 17: 132-134 (Abstract in Japanese).

Kisu, T., Kusaba, T., Yanase, Y., Sakai, K., Inaba, S., and Okochi, K. 1980. Family studies of hereditary deficiency of the ninth component of complement. Proceedings of the Complement Symposium 17: 135-137 (Abstract in Japanese).

Klemperer, M.R., Woodworth, H.C., Rosen, F.S., and Austen, K.F. 1966. Hereditary deficiency of the second component of complement $\left(C^{\prime} 2\right)$ in man. J. Clin. Invest. 45: 880-890.

Leddy, J.P., Frank, M.M., Gaither, T., Baum, J., and Klemperer, M.R. 1974. Hereditary deficiency of the sixth component of complement in man. J. Clin. Invest. 53: 544-553.

Lint, T.F., Zeitz, H.J., and Gewurz, H. 1980. Inherited deficiency of the ninth component of complement in man. J. Immunol. 125: 2252-2257.

Lim. D., Gewurz, A., Lint, T.F., Ghaze, M., Sepheri, B., and Gewurz, H. 1976. Absence of the sixth component of complement in a patient with repeated episodes of meningococcal meningitis. J. Pediatr. 89: 42-47.

Mayer, M.M. 1961. Complement and complement fixation. In Experimental Immunochemistry, 2nd ed., Kabat E.A. and Mayer, M.M., eds., Charles C. Thomas, Springfield, p. 133-240.

Nagaki, K., Fujikawa, K., and Inai, S. 1965. Studies on the fourth component of complement. II. The fourth component of complement in guinea pig and human platelets. Biken J. 8: 129-141.

Nelson, R.A., Jensen, J., Gigli, I., and Tamura, N. 1966. Methods for the separation, purification and measurement of nine components of hemolytic complement in guinea-pig serum. Immunochemistry 3 : 111-135.

Nemerow, G.R., Gewurz, H., Osofsky S.G., and Lint, T.F. 1978. Inherited deficiency of the seventh component of complement associated with nephritis. J. Clin. Invest. 61: 1602-1610.

Okochi, K., and Inaba, S. 1980. Anti-C9 found after transfusion in a patient with C9 deficiency. Proceedings of Joint Meeting of the 18th Congress of the International Society of Hematology and the 16th Congress of the International Society of Blood Transfusion. p. 210.

Otsuka, M. 1980 . personal communication.

Pariser, K.M., Raum, D., Berkman, E.M., Alper, C.A., and Agnello, V. 1978. Evidence for a silent or null gene in hereditary C2 deficiency. J. Immunol. 121: 2580-2581.

Petersen, B.H., Graham, J.A., and Brooks, G.F. 1976. Human deficiency of the eighth component of complement. J. Clin. Invest. 57: 283-290.

Pickering, R.J., Michael, A.F., Jr., Herdman, R.C., Good, R.A., and Gewurz, H. 1971. The complement system in chronic glomerulonephritis: three newly associated aberrations. $J$. Pediatr. 78: $30-43$.

Pondman, K.W., Stoop, J.W., Cormane, R.H., and Hannema, A.J. 1968. Abnormal C'1 in a patient with systemic lupus erythematosus. J. Immunol. 101: $811 \mathrm{~A}$.

Rosenfeld, S.I., Kelly, M.E., and Leddy, J.P. 1976. Hereditary deficiency of the fifth component of complement in man. J. Clin. Invest. 57: 1626-1634.

Sato, H. 1980. personal communication.

Snyderman, R., Durack, D.T., McCarty, G.A., Ward, F.E., and Meadows, L. 1979. Deficiency of the fifth component of complement in human subjects. Am. J. Med. 67: 638-645. 
Thompson, R.A., and Lachmann, P.J. 1977. A second case of human C3b inhibitor (KAF) deficiency. Clin. exp. Immunol. 27: 23-29.

Yukiyama, Y., Chihara, T., Tanimoto, K., Hirose, S., and Horiuchi, Y. 1979. Hereditary deficiency of the ninth component of complement (C9). Proceedings of the Complement Symposium 16: 190 (Abstract). 